\title{
Factors That Influence Entrepreneurial Intention within University Students in Egypt
}

\author{
Assem Sharaf, Alaa El-Gharbawy, Mohamed A. Ragheb \\ The Arab Academy for Science and Technology \& Maritime Transport, Alexandria, Egypt \\ Email: alaagharbawy@yahoo.com,raghebmm@aast.edu
}

How to cite this paper: Sharaf, A., El-Gharbawy, A. and Ragheb, M.A. (2018) Factors That Influence Entrepreneurial Intention within University Students in Egypt. Open Access Library Journal, 5: e4881.

https://doi.org/10.4236/oalib.1104881

Received: September 5, 2018

Accepted: October 7, 2018

Published: October 10, 2018

Copyright $\odot 2018$ by authors and Open Access Library Inc.

This work is licensed under the Creative Commons Attribution International License (CC BY 4.0).

http://creativecommons.org/licenses/by/4.0/

\begin{abstract}
The current research aims to propose a framework of the effects of behavioral factors of theory of planned behavior and psychological traits factors on students' entrepreneurial intention, measuring the size of effect, the circumstances under which the effect is clearly observed and studying the weighted effect of each of the behavior and traits elements. A questionnaire was adopted from previous studies and directed to students in the Egyptian universities. A total number of 430 respondents were considered and data were analyzed using AMOS through conducting SEM models for examining the effect of behavior and traits. Results showed that there is a significant effect of attitude toward behavior on students' entrepreneurial intention, while there is an insignificant effect of traits.
\end{abstract}

\section{Subject Areas}

Entrepreneurship, Socioeconomics

\section{Keywords}

Behavior, Psychological Traits, Entrepreneurial Intention, Theory of Planned Behavior, Entrepreneurship Education, Perceived Behavior Control

\section{Introduction}

Entrepreneurship is increasingly recognized as an important generator of growth, innovation and especially new job creation. As a result of that, there is progressively academic, political and corporate interest in entrepreneurship enhancing. The importance of entrepreneurship education has increased due to the need to prepare students for coping in the contemporary work and living environment. In addition to entrepreneurship courses taught for business students. This paper aims to advance an understanding of the impact of behavioral and 
psychological factors that influence Entrepreneurial Intention (EI) to become an entrepreneur within university students in the Egyptian context.

The paper has several objectives which are: identifying to what extent do the selected variables (attitude toward being an entrepreneur, perceived behavioral control, subjective norms and social valuation, propensity to take risk, self-confidence, need for achievement, tolerance for ambiguity, innovativeness, locus of control) correlate with students' entrepreneurial intention; and, finally, exploring which of these variables can best predict students' entrepreneurial intension to become an entrepreneur.

\section{Literature Review}

This section provides a review of the salient literature relating to the following constructs pertinent to this study within the published research areas of Entrepreneurial Intention, entrepreneurial behavioral antecedents, entrepreneurial psychological characteristics and entrepreneurial education. There are many options, opinions and ideas regarding teaching entrepreneurship within university business schools as well as many challenges in determining successful techniques that achieve outcomes in this venue.

\subsection{Entrepreneurial Intention}

Intention was identified as a Mental state that inspire a person to a specific goal or a path Bird and West [1]. Moreover, Fayole et al. [2] believed that intention as a cognitive representation of a human's will toward a certain behavior. According to Maresch et al. [3], the stronger a person's intention to execute a given behavior, the more likely that this behavior will be implemented. Further, Krueger and Brazeal [4] specified entrepreneurial intention as the person adherence towards future behavior that is estimated as the intention toward starting a new business or an organization. They also assure the importance of intentions key factors in predicting planned behavior.

Entrepreneurial Intention plays a vital role in the progression of becoming an entrepreneur. It is one of the key elements that contributes to the formation and growth of entrepreneurship, fosters autonomy and leads to initiatives as explained by Al-Shammari and Waleed [5]. Entrepreneurship literature shows that concrete intentions play a crucial role in making decisions to start a new business as argued by Krueger et al. [6]. Entrepreneurship is considered to be an intentionally planned behavior. Consequently, observing intentions towards the entrepreneurial behavior can help in predicting this behavior. Prior research indicates that specific behaviors such as entrepreneurship can be predicted with considerable accuracy from intentions to engage in the behaviors under consideration such as Souitaris et al. [7].

It was also found that greater growth aspiration was significantly associated with higher business growth by Wiklund and Shepherd [8] and entrepreneurial intentions are significantly related to entrepreneurial behavior as found by 
Zhang and Yang [9]. As a result, the study of entrepreneurial intention is vital to understand how to encourage entrepreneurial activity and behavior to emerge, Grid and Bargraim [10]. As an important phenomenon, entrepreneurial intention has attracted important cognitive research supporting a framework that underlies entrepreneurship as intentional behavior. Entrepreneurship literature shows that concrete intentions play a crucial role in making decisions to start a new business as declared by Kautonen et al. [11].

These entrepreneurial responsibilities may correspond to a range of psychological characteristics that define an individual's personality: locus of control; self-confidence and the need for achievement, Nitu-Antonie and Feder [12] describing the ability of the individual to control what happens in his/her life, Islam et al. [13]; inclination towards risk-taking, Nitu-Antonie et al. [14]. Personality is considered to have a strong influence on entrepreneurial intention and action to become an entrepreneur, Utsch and Rauch [15].

As declared by Raush and Ferse [16] that locus of control, propensity to take risk, self-efficacy, need for achievement, tolerance for ambiguity, and innovativeness are psychological characteristics associated with entrepreneurship would predict entrepreneurial attitudes. Entrepreneurial Intention would be a preceding and determining factor for engaging in business behaviors, Kolvereid [17]. Therefore, the intention to undertake a specific behavior will depend on the attitudes of persons to such behaviors, Ajzen [18]. More favorable attitudes will foster more viable intentions to implement a specific behavior and vice-versa, Linan and Chen [19]. Based on this latter approach, some entrepreneurship-based research models emerged and proposing cognitive premises for explaining such phenomena. Ajzen's theory of planned behavior (TPB) became one of the main theoretical models and adopted widely for research projects approaching EI, Linan [20].

\subsection{Behavioral Approach: Theory of Planned Behavior}

The TPB model has been identified within international research as one of the most promising approaches for understanding entrepreneurial intentions and decisions. According to the TPB model, entrepreneurial intention is conditioned by the attitudinal, normative and control type beliefs of individuals; however, in a holistic approach, it also considers individual variables (gender identity, entrepreneurship education, role models, etc.) and personality traits as argued by Raush and Hulsink [21] which may increase its relevance.

Empirical studies measuring behavioral characteristics construct through personal attitude, subjective norms and perceived behavioral control, considered them as antecedents of the entrepreneurial intention construct such as Schlaegel and Koenig [22]. Some studies emphasized that personal attitude and perceived behavioral control were positively and significantly related to entrepreneurial intentions and social norms had no significant influence, Robledo et al. [23], being considered a less relevant factor in substantiating entrepreneurial intent, 
Fretschner and Weber [24]. In some recent empirical studies, subjective norms and perceived control over own behavior appear as determinants of entrepreneurial intention such as Awang et al. [25].

Subjective norms also had a positive significant impact on entrepreneurial intentions when the investigated sample included nascent entrepreneurs as found by [11]. Kautonen et al. [26] observed that subjective norms have the highest effect on entrepreneurial intentions of all behavioral characteristics, while Liñán et al. [27] did not achieved the same results.

Feder and Antonie [28] explored the antecedents of the entrepreneurial intentions in the case of youth beneficiaries of entrepreneurial higher education studies and/or entrepreneurial role models, being grounded in the theoretical framework of rational action and planned behavior (TPB). They found that entrepreneurial higher education training and behavioral characteristics are significant and direct predictors of entrepreneurial intentions; behavioral characteristics also mediates the influence of psychological characteristics and of parental or social environmental specific entrepreneurial role models on entrepreneurial intentions.

Fietze and Boyd [29] found that students prefer a career as employee showing a low EI. Henley et al. [30] argued that Leadership skills, indicative of bridging cognitive social capital, are found to be strongly and significantly associated with entrepreneurial intentions through the mediating role of the core TPB constructs. Shah and Soomro [31] explained that attitudes toward behavior and subjective norms have a positive and significant relationship with entrepreneurial intention. On the other hand, perceived behavioral control has no significant relationship with entrepreneurial intention.

Yaghoubi-Farani et al. [32] showed that entrepreneurial education is needed to improve students' skills and knowledge and enhance their EI and perceived behavioral control. In addition, it is important to expose students to entrepreneurial role models and their businesses and to promote entrepreneurial careers as desirable and feasible options that may bring more advantages than working in the government or private sector.

\subsection{Entrepreneurial Psychological Traits Approach}

Regarding Psychological characteristics, they have been considered in this study because they are the most often mentioned characteristics for the study of entrepreneurship success and relationship between them and entrepreneurship has been evident in literatures such as Chatterjee and Das [33]. The literature has identified many characteristics as associated to entrepreneurship and including: the locus of control, the propensity to risk, self-confidence, the need for achievement, the tolerance for ambiguity and the capacity to innovate see for example Srivastava and Misra [34].

As stressed by Obschonka and Stuetzer [35], even though some limitations that have been pointed out are significant, "understanding the psychological na- 
ture and development of the individual entrepreneur is at the core of contemporary entrepreneurship research". Çolakoğlu and Gözükara, [36] explained in their study to compare personality traits (need for achievement, innovativeness, propensity to risk-taking, tolerance to ambiguity and internal locus of Control) based on the attitudes of university students toward entrepreneurship, that students with entrepreneurial intention are more innovative, have higher need for achievement and greater internal locus of control than those who do not have such intention.

Karabulut [37], explored in his research the effects of the personality Traits namely; Internal locus of control, need for achievement, risk tolerance, and entrepreneurial alertness, on the entrepreneurial intention, that the personality traits had a positive effect on the entrepreneurial intention. Khuong and An [38], examined the effects of personal traits (internal locus of control, risk-taking propensity, autonomy, tolerance of ambiguity, the need for autonomy, energy level, creativity and need for achievement), prior entrepreneurial experience, external environment, social norm and perceived feasibility on entrepreneurship intention through the positive and negative perception toward entrepreneurship.

Chaudhary [39] investigated in a study the influence of social and personal dispositional factors on determining the entrepreneurial inclination. The result shows that the traits of locus of control, tolerance for ambiguity, self-confidence and innovativeness were significant in differentiating entrepreneurs from non-entrepreneurs. At the same time, it was also observed that need for achievement and risk-taking propensity were not found to be significantly different for these two groups which was contradictory to the expectations. Nasip et al., [40] stated that innovativeness, self-confidence, propensity to take risk, need for achievement and tolerance for ambiguity are positively related to entrepreneurial intention among undergraduate students. However, locus of control is not significantly related to entrepreneurial intention.

This paper is designed to fill the gap in literature by examining the effect of behavior and traits in the Egyptian context. The following section presents the research framework and hypotheses tested in this study.

\section{Research Framework}

This research framework is identified as in Figure 1, where the relationship is examined through the hypotheses shown. A questionnaire was adopted from the studies of Alshammari and Waleed [5] and Nasip et al. [40] to test the assigned relations. This study will use a convenience sampling technique. As its name implies, convenience sampling refers to the collection of information from members of the population who are conveniently available to provide it as stated by Sekaran and Bougie [41]. In the questionnaire assigned, the questions were adopted to measure the dimensions under study by implementing a 5-point $\mathrm{Li}$ kert -scale used for all responses with $(1=$ Strongly Disagree, $2=$ Disagree, $3=$ Neutral, $4=$ Agree, 5 = Strongly Agree). 


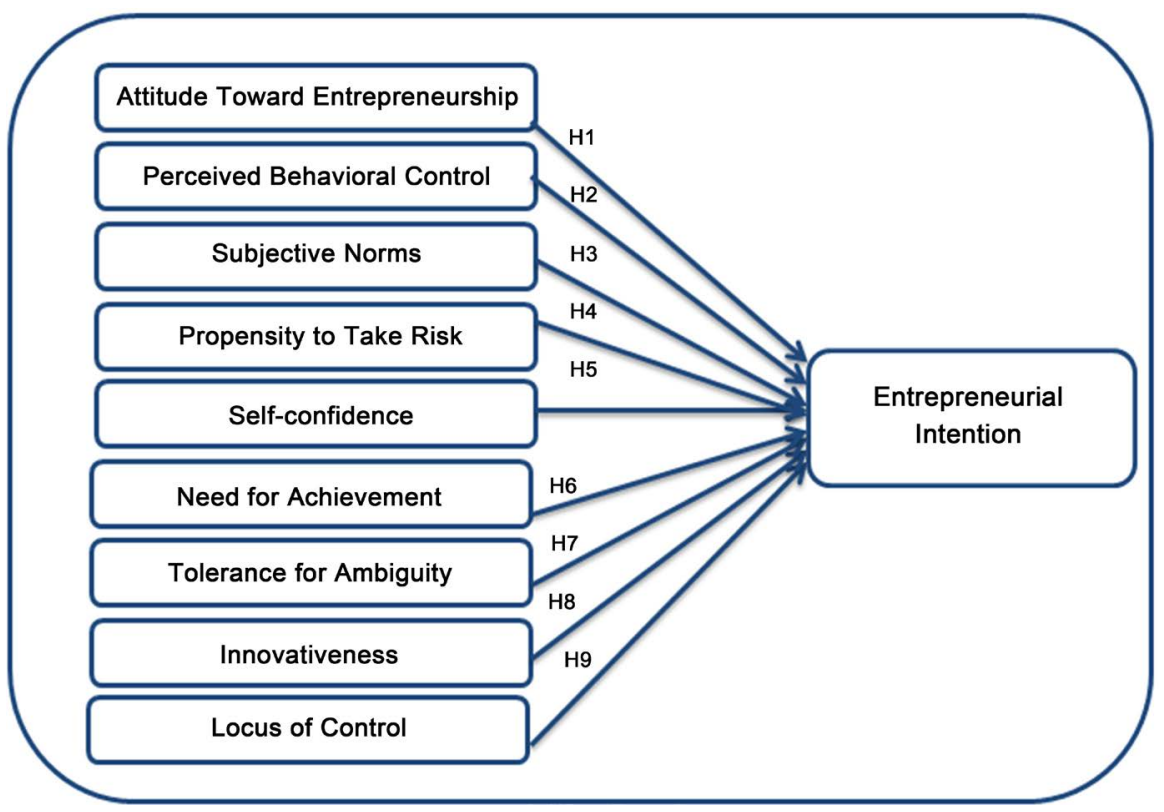

Figure 1. Research framework for the current study.

The following hypotheses were developed from theoretical framework, as follows:

$\mathrm{H}_{1}$ : There is a significant relationship between Attitude toward entrepreneurship and Entrepreneurial Intention.

$\mathrm{H}_{2}$ : There is a significant relationship between Perceived Behavioral Control and Entrepreneurial Intention.

$\mathrm{H}_{3}$ : There is a significant relationship between Subjective Norms and Entrepreneurial Intention.

$\mathrm{H}_{4}$ : There is a significant relationship between Propensity to take risk and Entrepreneurial Intention.

$\mathrm{H}_{5}$ : There is a significant relationship between Self-confidence and Entrepreneurial Intention.

$\mathrm{H}_{6}$ : There is a significant relationship between Need for achievement and Entrepreneurial Intention.

$\mathrm{H}_{7}$ : There is a significant relationship between Tolerance for ambiguity and Entrepreneurial Intention.

$\mathrm{H}_{8}$ : There is a significant relationship between Innovativeness and Entrepreneurial Intention.

$\mathrm{H}_{9}$ : There is a significant relationship between Locus of Control and Entrepreneurial Intention.

\section{Results and Findings}

To test the hypotheses mentioned above, the current research used regression analysis and structural equation modeling (SEM). This requires testing the validity and reliability of the research variables as well as presenting a descriptive analysis of the research variables under study. After that, the researcher will 
present the hypotheses testing through the model constructed. As a preliminary step, the frequency tables are computed for the research variables. To test the validity of the research variables, confirmatory factor analysis was used to calculate the Average Variance Extracted (AVE) and Factor Loading (FL) of each construct. Therefore, confirmatory factor analysis using the principal component method was used to examine the convergent validity of the research dimensions. Reliability test is an assessment of the degree of consistency between multiple measurements of a variable. Cronbach's alpha is the most widely used measurement tool with a generally agreed lower limit of 0.7 . Table 1 provides an overview of the validity and reliability scores.

Table 2 shows the frequency tables for the research variables, where it could be observed that responses vary between Neutral and Agree, which means that not all responses are in the zone of agreement. In other words, the sample under study faces a problem as the respondents' reactions were not all in the agreement zone thus, in this study testing of hypothesis will be observed to identify which variables direct customers to be in the disagreement zone.

Table 3 shows the SEM analysis of the impact of Behavioral Antecedents; Attitude toward entrepreneurship, Perceived behavior control and Subjective Norms on Entrepreneurial Intention. It could be observed that there is a positive significant impact of Attitude toward entrepreneurship on Entrepreneurial Intention, as the estimate is 0.879 , as well as P-value is less than 0.05 . On the other hand, Perceived behavior control and Subjective Norms show insignificant effect on Entrepreneurial Intention as $\mathrm{P}$-value is more than 0.05 . However, the $\mathrm{R}$ square is 0.833 , which means that the model explains $83.3 \%$ of the variation in Entrepreneurial Intention.

The model fit indices; $\mathrm{CMIN} / \mathrm{DF}=2.807, \mathrm{GFI}=0.951, \mathrm{CFI}=0.958, \mathrm{AGFI}=$ 0.916 , and RMSEA $=0.065$ are all within their acceptable levels. The SEM model conducted for the effect of Behavioral Antecedents on Entrepreneurial Intention is illustrated in Figure 2.

Table 4 shows the SEM analysis of the impact of Entrepreneurial Psychological Traits; Need for achievement, Locus of control, Self-confidence, Propensity to take risk, Need for achievement, Locus of control and Tolerance for ambiguity, Tolerance for ambiguity and Innovativeness. It could be observed that there is an insignificant effect on Entrepreneurial Intention as P-values are more than 0.05 . However, the $\mathrm{R}$ square is 0.363 , which means that the model explains $36.3 \%$ of the variation in Entrepreneurial Intention.

The model fit indices; $\mathrm{CMIN} / \mathrm{DF}=1.940, \mathrm{GFI}=0.952$, CFI $=0.966, \mathrm{AGFI}=$ 0.925 , and RMSEA $=0.047$ are all within their acceptable levels (Table 5). The SEM model conducted for the effect of Behavior Dimensions on Entrepreneurial Intention is illustrated in Figure 3.

\section{Conclusion}

This study seeks to fill the gap by empirically examining university students' EIs, 
Table 1. Validity and reliability tests.

\begin{tabular}{|c|c|c|c|c|c|}
\hline Variables & KMO & AVE & Cronbach's Alpha & Items & Factor Loading \\
\hline \multirow{5}{*}{$\begin{array}{l}\text { Attitude toward } \\
\text { entrepreneurship }\end{array}$} & \multirow{5}{*}{0.821} & \multirow{5}{*}{$63.585 \%$} & \multirow{5}{*}{0.842} & Item 1 & 0.767 \\
\hline & & & & Item 2 & 0.467 \\
\hline & & & & Item 3 & 0.771 \\
\hline & & & & Item 4 & 0.719 \\
\hline & & & & Item 5 & 0.454 \\
\hline \multirow{8}{*}{ Perceived behavior control } & \multirow{8}{*}{0.836} & \multirow{8}{*}{$56.628 \%$} & \multirow{8}{*}{0.844} & Item 1 & 0.543 \\
\hline & & & & Item 2 & 0.638 \\
\hline & & & & Item 3 & Rephrased \\
\hline & & & & Item 4 & Rephrased \\
\hline & & & & Item 5 & 0.492 \\
\hline & & & & Item 6 & 0.588 \\
\hline & & & & Item 7 & 0.533 \\
\hline & & & & Item 8 & 0.604 \\
\hline \multirow{8}{*}{ Subjective norms } & \multirow{8}{*}{0.732} & \multirow{8}{*}{$58.749 \%$} & \multirow{8}{*}{0.821} & Item 1 & 0.458 \\
\hline & & & & Item 2 & 0.595 \\
\hline & & & & Item 3 & 0.664 \\
\hline & & & & Item 4 & Rephrased \\
\hline & & & & Item 5 & 0.615 \\
\hline & & & & Item 6 & 0.629 \\
\hline & & & & Item 7 & Rephrased \\
\hline & & & & Item 8 & Rephrased \\
\hline \multirow{7}{*}{ Locus of control } & \multirow{7}{*}{0.671} & \multirow{7}{*}{$55.681 \%$} & \multirow{7}{*}{0.731} & Item 1 & Rephrased \\
\hline & & & & Item 2 & 0.655 \\
\hline & & & & Item 3 & 0.599 \\
\hline & & & & Item 4 & Rephrased \\
\hline & & & & Item 5 & Rephrased \\
\hline & & & & Item 6 & 0.456 \\
\hline & & & & Item 7 & 0.517 \\
\hline \multirow{6}{*}{ Propensity to take risk } & \multirow{6}{*}{0.645} & \multirow{6}{*}{$55.282 \%$} & \multirow{6}{*}{0.727} & Item 1 & Rephrased \\
\hline & & & & Item 2 & 0.562 \\
\hline & & & & Item 3 & 0.514 \\
\hline & & & & Item 4 & 0.565 \\
\hline & & & & Item 5 & 0.570 \\
\hline & & & & Item 6 & Rephrased \\
\hline \multirow{3}{*}{ Self confidence } & \multirow{3}{*}{0.617} & \multirow{3}{*}{$61.107 \%$} & \multirow{3}{*}{0.722} & Item 1 & 0.525 \\
\hline & & & & Item 2 & 0.687 \\
\hline & & & & Item 3 & Rephrased \\
\hline
\end{tabular}




\section{Continued}

\begin{tabular}{|c|c|c|c|c|c|}
\hline & & & & Item 4 & Rephrased \\
\hline & & & & Item 5 & Rephrased \\
\hline & & & & Item 6 & 0.438 \\
\hline & & & & Item 1 & 0.649 \\
\hline & & & & Item 2 & 0.534 \\
\hline & & & & Item 3 & 0.568 \\
\hline Need for acnievement & 0.748 & $53.1 / 9 \%$ & 0.153 & Item 4 & Rephrased \\
\hline & & & & Item 5 & 0.480 \\
\hline & & & & Item 6 & Rephrased \\
\hline & & & & Item 1 & 0.590 \\
\hline & & & & Item 2 & 0.749 \\
\hline Tolom forombiruity & 0564 & $507700 \%$ & $0-700$ & Item 3 & Rephrased \\
\hline & & & & Item 4 & Rephrased \\
\hline & & & & Item 5 & 0.424 \\
\hline & & & & Item 6 & Rephrased \\
\hline & & & & Item 1 & Rephrased \\
\hline & & & & Item 2 & 0.720 \\
\hline Innovativeness & 0.696 & $68.912 \%$ & 0.774 & Item 3 & 0.650 \\
\hline & & & & Item 4 & 0.698 \\
\hline & & & & Item 5 & Rephrased \\
\hline & & & & Item 1 & 0.529 \\
\hline & & & & Item 2 & 0.615 \\
\hline Entrepreneurial Intention & 0.794 & $61.774 \%$ & 0.843 & Item 3 & 0.697 \\
\hline & & & & Item 4 & 0.714 \\
\hline & & & & Item 5 & 0.533 \\
\hline
\end{tabular}

Table 2. Descriptive analysis for the research variables.

\begin{tabular}{ccccccccc}
\hline & \multirow{2}{*}{$\mathrm{N}$} & Mean & Std. Deviation & \multicolumn{5}{c}{ Frequency } \\
\cline { 5 - 9 } & & & & 1 & 2 & 3 & 4 & 5 \\
\hline Attitude toward entrepreneurship & 430 & 3.7279 & 0.91499 & 8 & 25 & 131 & 178 & 88 \\
Perceived behavior control & 430 & 3.3209 & 0.76903 & 7 & 30 & 240 & 124 & 29 \\
Subjective norms & 430 & 3.5884 & 0.72282 & 1 & 31 & 138 & 234 & 26 \\
Locus of control & 430 & 3.3256 & 0.68690 & 5 & 20 & 254 & 132 & 19 \\
Propensity to take risk & 430 & 3.5233 & 0.73422 & 4 & 26 & 165 & 211 & 24 \\
Self confidence & 430 & 3.3651 & 0.72850 & 7 & 25 & 220 & 160 & 18 \\
Need for achievement & 430 & 3.4581 & 0.72057 & 4 & 22 & 201 & 179 & 24 \\
Tolerance for ambiguity & 430 & 3.4488 & 0.73914 & 8 & 11 & 220 & 162 & 29 \\
Innovativeness & 430 & 3.5326 & 0.71781 & 4 & 20 & 174 & 207 & 25 \\
Entrepreneurial intention & 430 & 3.8698 & 0.83444 & 9 & 16 & 79 & 244 & 82 \\
\hline
\end{tabular}


Table 3. SEM analysis of behavior dimensions on entrepreneurial intention.

\begin{tabular}{lllll}
\hline & & Estimate & P-value & R Square \\
\hline EI $<---$ & Attitude toward entrepreneurship & 0.897 & $* * *$ & \\
EI $<---$ & Perceived behavior control & 0.098 & 0.126 & 0.833 \\
EI $<---$ & Subjective norms & -0.130 & 0.089 & \\
\hline
\end{tabular}

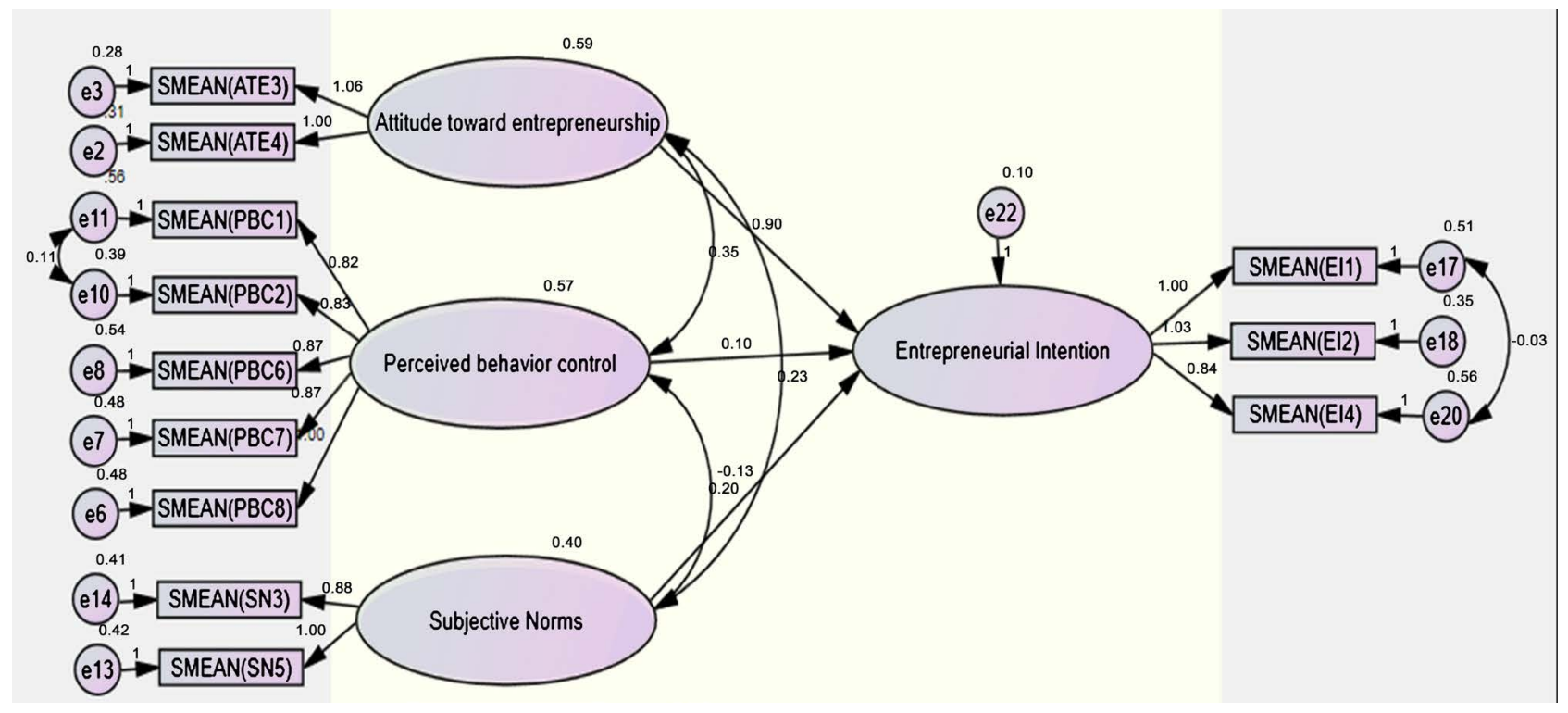

Figure 2. SEM for behavioral antecedents on entrepreneurial intention.

Table 4. SEM analysis of entrepreneurial psychological traits on entrepreneurial intention.

\begin{tabular}{lccccc}
\hline & & & Estimate & P-value & R Square \\
\hline EI & $<---$ & Need for achievement & -0.198 & 0.721 & \\
EI & $<---$ & Locus of control & -0.245 & 0.052 & \\
EI & $<---$ & Self confidence & 0.239 & 0.170 & \multirow{2}{*}{0.363} \\
EI & $<---$ & Propensity to take risk & 0.176 & 0.050 & \\
EI & $<---$ & Tolerance for ambiguity & -0.074 & 0.510 & \\
EI & $<---$ & Innovativeness & 0.554 & 0.139 & \\
\hline
\end{tabular}

Table 5. Summary of research hypotheses.

\begin{tabular}{lll}
\hline Hypothesis & Description & Results \\
\hline $\mathrm{H}_{1}$ & There is a significant relationship between Attitude toward entrepreneurship and EI & Supported \\
$\mathrm{H}_{2}$ & There is a significant relationship between Perceived Behavioral Control and EI & Not Supported \\
$\mathrm{H}_{3}$ & There is a significant relationship between Subjective Norms and EI & Not Supported \\
$\mathrm{H}_{4}$ & There is a significant relationship between Propensity to take risk and EI & Not Supported \\
$\mathrm{H}_{5}$ & There is a significant relationship between Self-confidence and EI & Not Supported \\
$\mathrm{H}_{6}$ & There is a significant relationship between Need for achievement and EI & Not Supported \\
$\mathrm{H}_{7}$ & There is a significant relationship between Tolerance for ambiguity and EI & Not Supported \\
$\mathrm{H}_{8}$ & There is a significant relationship between Innovativeness and EI & Not Supported \\
$\mathrm{H}_{9}$ & There is a significant relationship between Locus of Control and EI & Not Supported \\
\hline
\end{tabular}




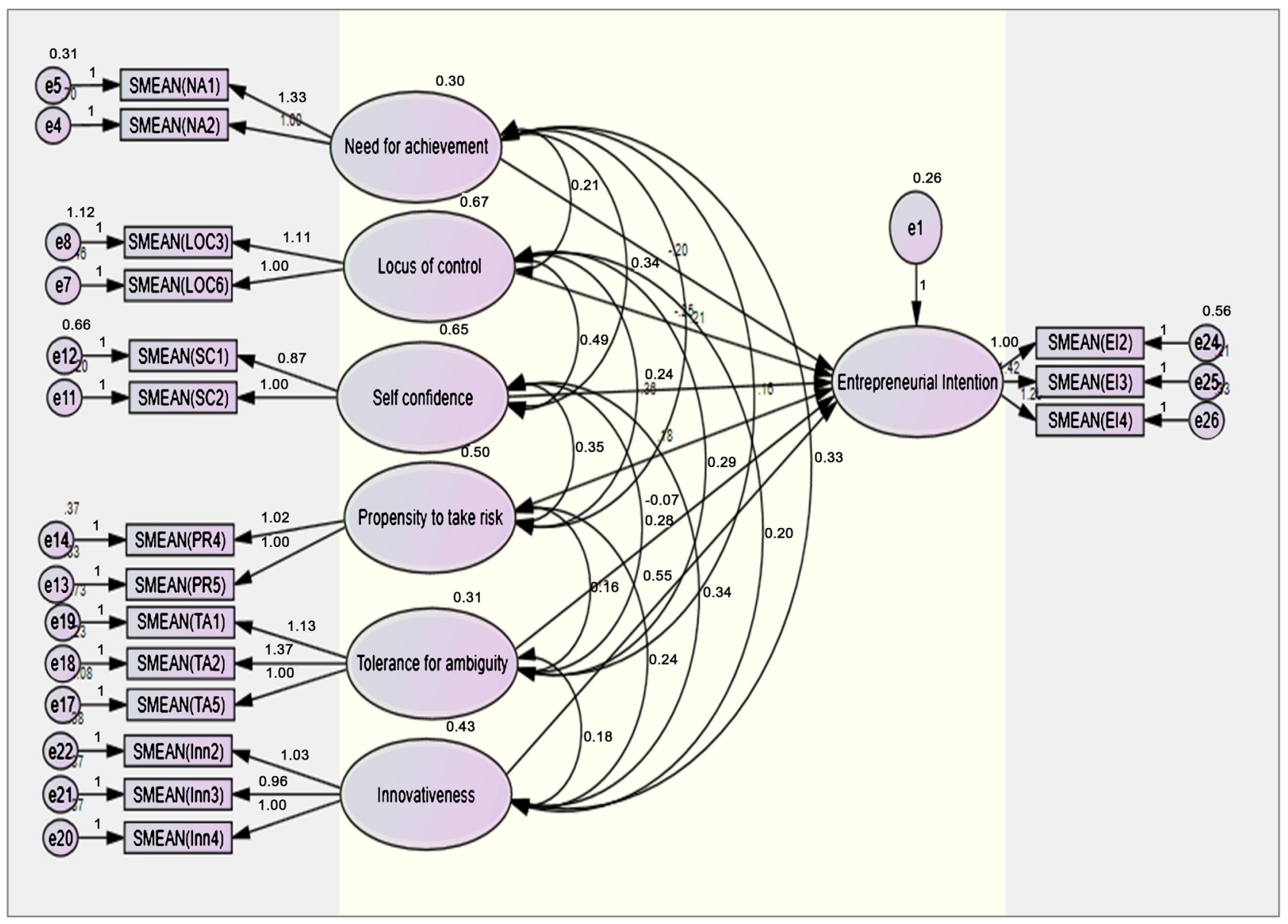

Figure 3. SEM for entrepreneurial psychological traits on entrepreneurial intention.

motivations and concerns about starting a business in Egypt. It was found that there is a significant effect of attitude toward entrepreneurship on entrepreneurial intention of students in the Egyptian context, while there is an insignificant effect of other variables on entrepreneurial intention.

\section{Conflicts of Interest}

The authors declare no conflicts of interest regarding the publication of this paper.

\section{References}

[1] Bird, B.J. and West III, G.P. (1998) Time and Entrepreneurship. Entrepreneurship Theory and Practice, 22, 5-9. https://doi.org/10.1177/104225879802200201

[2] Fayolle, A., Gailly, B. and Lassas-Clerc, N. (2006) Assessing the Impact of Entrepreneurship Education Programmes: A New Methodology. Journal of European Industrial Training, 30, 701-720. https://doi.org/10.1108/03090590610715022

[3] Maresch, D., Harms, R., Kailer, N. and Wimmer-Wurm, B. (2016) The Impact of Entrepreneurship Education on the Entrepreneurial Intention of Students in Science and Engineering versus Business Studies University Programs. Technological Forecasting and Social Change, 104, 172-179.

https://doi.org/10.1016/j.techfore.2015.11.006 
[4] Krueger Jr, N.F. and Brazeal, D.V. (1994) Entrepreneurial Potential and Potential Entrepreneurs. Entrepreneurship Theory and Practice, 18, 91-104. https://doi.org/10.1177/104225879401800307

[5] Al-Shammari, M. and Waleed, R. (2018) Entrepreneurial Intentions of Private University Students in the Kingdom of Bahrain. International Journal of Innovation Science, 10, 43-57. https://doi.org/10.1108/IJIS-06-2017-0058

[6] Krueger Jr, N.F., Reilly, M.D. and Carsrud, A.L. (2000) Competing Models of Entrepreneurial Intentions. Journal of Business Venturing, 15, 411-432. https://doi.org/10.1016/S0883-9026(98)00033-0

[7] Souitaris, V., Zerbinati, S. and Al-Laham, A. (2007) Do Entrepreneurship Programmes Raise Entrepreneurial Intention of Science and Engineering Students? The Effect of Learning, Inspiration and Resources. Journal of Business Venturing, 22, 566-591. https://doi.org/10.1016/j.jbusvent.2006.05.002

[8] Wiklund, J. and Shepherd, D. (2005) Entrepreneurial Orientation and Small Business Performance: A Configurational Approach. Journal of Business Venturing, 20, 71-91. https://doi.org/10.1016/j.jbusvent.2004.01.001

[9] Zhang, Y. and Yang, J. (2006) New Venture Creation: Evidence from an Investigation into Chinese Entrepreneurship. Journal of Small Business and Enterprise Development, 13, 161-173. https://doi.org/10.1108/14626000610665872

[10] Gird, A. and Bagraim, J.J. (2008) The Theory of Planned Behaviour as Predictor of Entrepreneurial Intent amongst Final-Year University Students. South African Journal of Psychology, 38, 711-724. https://doi.org/10.1177/008124630803800410

[11] Kautonen, T., van Gelderen, M. and Fink, M. (2015) Robustness of the Theory of Planned Behavior in Predicting Entrepreneurial Intentions and Actions. Entrepreneurship Theory and Practice, 39, 655-674. https://doi.org/10.1111/etap.12056

[12] Nitu-Antonie, R.D. and Feder, E.S. (2015) The Role of Economic Academic Education on Entrepreneurial Behaviour. Amfiteatru Economic Journal, 17, 261-276.

[13] Islam, M.A., Khan, M.A., Obaidullah, A.Z.M. and Alam, M.S. (2011) Effect of Entrepreneur and Firm Characteristics on the Business Success of Small and Medium Enterprises (SMEs) in Bangladesh. International Journal of Business and Management, 6, 289.

[14] Nitu-Antonie, R.D., Sirghi, N., Hatega, C.D., Feder, E.S. and Ramona Socoliuc, O. (2014) Education-Vector of Entrepreneurship Development. Transformations in Business \& Economics, 13.

[15] Utsch, A. and Rauch, A. (2000) Innovativeness and Initiative as Mediators between Achievement Orientation and Venture Performance. European Journal of Work and Organizational Psychology, 9, 45-62. https://doi.org/10.1080/135943200398058

[16] Rauch, A. and Frese, M. (2007) Let's Put the Person Back into Entrepreneurship Research: A Meta-Analysis on the Relationship between Business Owners' Personality Traits, Business Creation, and Success. European Journal of Work and Organizational Psychology, 16, 353-385. https://doi.org/10.1080/13594320701595438

[17] Kolvereid, L. (1996) Prediction of Employment Status Choice Intentions. Entrepreneurship Theory and Practice, 21, 47-58. https://doi.org/10.1177/104225879602100104

[18] Ajzen, I. (1991) The Theory of Planned Behavior. Organizational Behavior and Human Decision Processes, 50, 179-211. https://doi.org/10.1016/0749-5978(91)90020-T

[19] Liñán, F. and Chen, Y.W. (2009) Development and Cross-Cultural Application of a 
Specific Instrument to Measure Entrepreneurial Intentions. Entrepreneurship Theory and Practice, 33, 593-617. https://doi.org/10.1111/j.1540-6520.2009.00318.x

[20] Liñán, F. (2008) Skill and Value Perceptions: How Do They Affect Entrepreneurial Intentions? International Entrepreneurship and Management Journal, 4, 257-272. https://doi.org/10.1007/s11365-008-0093-0

[21] Rauch, A. and Hulsink, W. (2015) Putting Entrepreneurship Education Where the Intention to Act Lies: An Investigation into the Impact of Entrepreneurship Education on Entrepreneurial Behavior. Academy of Management Learning \& Education, 14, 187-204. https://doi.org/10.5465/amle.2012.0293

[22] Schlaegel, C. and Koenig, M. (2014) Determinants of Entrepreneurial Intent: A Meta-Analytic Test and Integration of Competing Models. Entrepreneurship Theory and Practice, 38, 291-332. https://doi.org/10.1111/etap.12087

[23] Robledo, J.L.R., Arán, M.V., Sanchez, V.M. and Molina, M.Á.R. (2015) The Moderating Role of Gender on Entrepreneurial Intentions: A TPB Perspective. Intangible Capital, 11, 92-117.

[24] Fretschner, M. and Weber, S. (2013) Measuring and Understanding the Effects of Entrepreneurial Awareness Education. Journal of Small Business Management, 51, 410-428.

[25] Awang, A., Amran, S., Nor, M.N.M., Ibrahim, I.I. and Razali, M.F.M. (2016) Individual Entrepreneurial Orientation Impact on Entrepreneurial Intention: Intervening Effect of PBC and Subjective Norm. Journal of Entrepreneurship, Business and Economics, 4, 94-129.

[26] Kautonen, T., Van Gelderen, M. and Tornikoski, E.T. (2013) Predicting Entrepreneurial Behaviour: A Test of the Theory of Planned Behaviour. Applied Economics, 45, 697-707. https://doi.org/10.1080/00036846.2011.610750

[27] Liñán, F., Rodríguez-Cohard, J.C. and Rueda-Cantuche, J.M. (2011) Factors Affecting Entrepreneurial Intention Levels: A Role for Education. International Entrepreneurship and Management Journal, 7, 195-218. https://doi.org/10.1007/s11365-010-0154-Z

[28] Feder, E.S. and Nițu-Antonie, R.D. (2017) Connecting Gender Identity, Entrepreneurial Training, Role Models and Intentions. International Journal of Gender and Entrepreneurship, 9, 87-108. https://doi.org/10.1108/IJGE-08-2016-0028

[29] Fietze, S. and Boyd, B. (2017) Entrepreneurial Intention of Danish Students: A Correspondence Analysis. International Journal of Entrepreneurial Behavior \& Research, 23, 656-672. https://doi.org/10.1108/IJEBR-08-2016-0241

[30] Henley, A., Contreras, F., Espinosa, J.C. and Barbosa, D. (2017) Entrepreneurial Intentions of Colombian Business Students: Planned Behaviour, Leadership Skills and Social Capital. International Journal of Entrepreneurial Behavior \& Research, 23, 1017-1032. https://doi.org/10.1108/IJEBR-01-2017-0031

[31] Shah, N. and Soomro, B.A. (2017) Investigating Entrepreneurial Intention among Public Sector University Students of Pakistan. Education Training, 59, 841-855. https://doi.org/10.1108/ET-11-2016-0168

[32] Yaghoubi Farani, A., Karimi, S. and Motaghed, M. (2017) The Role of Entrepreneurial Knowledge as a Competence in Shaping Iranian Students' Career Intentions to Start a New Digital Business. European Journal of Training and Development, 41, 83-100. https://doi.org/10.1108/EJTD-07-2016-0054

[33] Chatterjee, N. and Das, N. (2015) Key Psychological Factors as Predictors of Entrepreneurial Success: A Conceptual Framework. Academy of Entrepreneurship Journal, 21, 102. 
[34] Srivastava, S. and Misra, R. (2017) Exploring Antecedents of Entrepreneurial Intentions of Young Women in India: A Multi-Method Analysis. Journal of Entrepreneurship in Emerging Economies, 9, 181-206.

https://doi.org/10.1108/JEEE-04-2016-0012

[35] Obschonka, M. and Stuetzer, M. (2017) Integrating Psychological Approaches to Entrepreneurship: The Entrepreneurial Personality System (EPS). Small Business Economics, 49, 203-231. https://doi.org/10.1007/s11187-016-9821-y

[36] Çolakoğlu, N. and Gözükara, İ. (2016) A Comparison Study on Personality Traits Based on the Attitudes of University Students toward Entrepreneurship. Procedia-Social and Behavioral Sciences, 229, 133-140. https://doi.org/10.1016/j.sbspro.2016.07.122

[37] Karabulut, A.T. (2016) Personality Traits on Entrepreneurial Intention. Procedia-Social and Behavioral Sciences, 229, 12-21. https://doi.org/10.1016/j.sbspro.2016.07.109

[38] Khuong, M.N. and An, N.H. (2016) The Factors Affecting Entrepreneurial Intention of the Students of Vietnam National University-A Mediation Analysis of Perception toward Entrepreneurship. Journal of Economics, Business and Management, 4, 104-111.

[39] Chaudhary, R. (2017) Demographic Factors, Personality and Entrepreneurial Inclination: A Study among Indian University Students. Education Training, 59, 171-187. https://doi.org/10.1108/ET-02-2016-0024

[40] Nasip, S., Amirul, S.R., Sondoh Jr., S.L. and Tanakinjal, G.H. (2017) Psychological Characteristics and Entrepreneurial Intention: A Study among University Students in North Borneo, Malaysia. Education Training, 59, 825-840. https://doi.org/10.1108/ET-10-2015-0092

[41] Sekaran, U. and Bougie, R. (2016) Research Methods for Business: A Skill-Building Approach. 7th Edition, Wiley \& Sons, West Sussex. 